


\section{CICONIA ALBA.}

Stork.

Ardea ciconia, Linn. Faun. Suec., p. 57.

Ciconia alba, Briss. Orn., tom. v. p. 365, pl. xxxii.

albescens, nivea, et candida, Brehm, Vög. Deutschl., pp. 574, 575.

THE Stork is one of the most conspicuous of migratory birds, and is specially interesting from the circumstance of its arrival and departure occurring with a precision which did not escape the notice of the inspired writers; for we read in Jeremiah, viii. 7, "Yea, the Stork in the heavens knoweth her appointed times." To witness the exactitude with which these movements are effected, my readers must proceed to certain parts of the neighbouring continent; for our islands are not in the direct line of the bird's migrations ; indeed the Stork has probably never been more than an accidental visitor to us; still we have abundant evidence of its occurrence in Britain, from the time of Willughby and Ray to the month in which I am writing (May 1871), when Mr. J. H. Gurney, Jun., showed me a fine old male in the flesh, which had been shot either at Dungeness or Romney, in Kent. On the Continent, particularly in Germany and Holland, the arrival of the Stork is regarded as the true harbinger of spring, and is looked for with the highest interest, as will be seen from the following passage in the clever work by MM. Erckmann and Chatrian, entitled 'Contes des Bords du Rhin,' to which my attention was directed by Professor Owen. The scene is from the story called “L'ami Fritz," chap. 8, page 31.

"At two o'clock entered Professor Speck, with his great square-toed shoes at the end of his long thin legs, his long brown coat, and his epicurean nose. He took off his hat with a solemn air, and said, 'I have the honour to announce to the company that the Storks have arrived!' Forthwith was repeated from every corner of the beer-house 'The Storks have arrived! the Storks have arrived!'

"A great tumult commenced; every one quitted his half-finished pint to go and look at the Storks. In less than a minute there were more than a hundred persons with their noses in the air in front of the 'Great Hart.' At the very top of the church a Stork, resting on her stilt-like legs, her black wings folded above her white tail, her large red beak inclined with a melancholy air, was the admiration of all the town. The male Stork whirled around, and tried to settle himself on the wheel, where still hung a few ends of straw. The Rabbi David had also arrived, and looking up, his old hat hanging at the back of his head, exclaimed 'They have come from Jerusalem! They have reposed on the Pyramids of Egypt ...; they have traversed the seas !' All along the street, in front of the market-house, nothing was seen but old gossips, old men, and children, their heads thrown back in a sort of extasy, some old women saying, while wiping their eyes, "We have seen them again, once more!"'

A detailed account of all the recorded instances of the occurrence of the Stork in England would be without any compensating amount of interest; I shall therefore merely remark that its visits are by no means regular, that in one year one, two, or more may appear, while in the next, or probably two or three years, none may be seen; the latest instance that has come to my knowledge is the one above mentioned, in which the bird was submitted to my inspection by Mr. Gurney.

Now what is the especial use of the Stork in the countries it regularly frequents, which renders it so great a favourite? The ridding of the low miasmic and heated marshes of the reptiles, fishes, and insects which abound in such situations, cleansing them as it were and keeping down putridity, just as the great Adjutant and the Kites clear away the offal from the cities of the east; in performing which useful task the young of many marsh-birds, Partridges, Larks, \&c. fall victims to its voracity; neither do moles, shrews, or leverets come amiss to it.

Besides being valued for its usefulness, its great size, noble and attractive bearing, and semidomestic disposition render it a general favourite with every one. In Holland and Germany it seldom breeds in the marsh or the forest, but, more familiar than the Rook, it seeks a closer association with man by resorting to ligh chimneys, the gable ends of houses, the towers of churches, and similar situations, an uplifted cartwheel, \&c., and thereon constructing its nest and rearing its young-each individual, if no mishap attends it during its winter sojourn elsewhere, returning in spring to the same site for the like purpose, and being greeted with a hearty welcome. How different is the reception given to any straggler to our islands! no sooner does it make its appearance than it is immediately pursued and generally shot.

Besides inhabiting Europe, Asia Minor, and Africa, the Stork frequents at one season or other the western 
portion of India, Amoorland, and probably China ; its range, therefore, is most extensive. In America it has never been seen, the Atlantic sea on the west and the North Pacific on the east forming barriers which it never crosses.

"The Stork," says Mr. Bennett, " has in all ages been regarded with peculiar favour, amounting in some countries almost to veneration, partly on account of the services it performs in the destruction of noxious animals and in removing impurities from the surface of the earth, and partly on account of its mildness of temper, the harmlessness of its habits, and the moral virtues with which the imagination has delighted to invest it. Among the ancient Egyptians the Stork was regarded with a reverence inferior only to that which was paid to the sacred Ibis. The same feeling is still prevalent in many parts of Africa and the East; and even in Switzerland and Holland something like superstition seems to mingle in the minds of the common people with the hospitable kindness which a strong conviction of its utility disposes them to evince towards this favourite bird . . . In numerous parts of Holland its nest, built on the chimney-top, remains undisturbed for many successive years, and the owners constantly return with unerring sagacity to the same spot. The joy which they manifest on again taking possession of their dwelling, and the attachment which they testify towards their benevolent hosts are familiar to every one. They generally lay from two to four eggs, of a dingy yellowish white, rather longer than those of a goose, but not so broad. The incubation lasts for a month, the male sharing in the task during the absence of the female in search of food. When the young. birds are hatched they are carefully fed by their parents, who watch over them with the closest anxiety. As soon as they are capable of flying, the parents exercise them in it by degrees, carrying them at first on their own wings, and then conducting them in short flights around their nest. In repose, the Stork is commonly seen standing upon one leg, with its long neck bent backwards and its head resting on its shoulder. Its motions are slow and measured, the length of its steps corresponding with that of its legs. In flight its head and neck are directed straight forwards, and its legs extended backwards, an awkward and apparently constrained position, but that which is best calculated for enabling it to cleave the air with rapidity. When migrating, the Storks appear gradually to assemble in one spot from the whole of the surrounding district to the number of many hundreds, making, when they meet, that peculiar clattering with their beaks which appears to serve them in the place of voice. As soon as their number is completed, the entire body mount at once into the air without noise or confusion, and are speedily lost sight of in the loftiuess of their flight." - Gardens and Menagerie of the Zoological Society delineated, vol. i.

“ I shall never forget," says Mr. Gurney, Jun., “the interest I took in a Stork's nest at Medea, in Algeria. It was placed in one of two chimueys at the gable end of by no means the largest house in the town. I watched it for hours. The old birds were constantly repairing it and moving about the sticks ; and although it was small, both birds found room to stand in it at the same time. The bird leaves the nest with a spring, and gets quite clear before it expands its huge wings, but does not draw in its legs, which hang down awkwardly at first and then stream out behind. When it alights the legs are cast upwards and sideways."

Speaking of the bird as observed in Palestine, the Rev. H. B. Tristram says :- "The White Stork is a regular though only a passing migrant. During the whole of April it covers the land, suddenly appearing in the south, and moving northwards a few miles a day. Thus we were told by some travellers who came up to Gennesaret that the whole country about Samaria was covered with Storks. Two days afterwards they overspread our neighbourhood, not close together, but scattered over lill and valley, plain and marsh alike, steadily quartering the ground, seldom near one another, but generally about a hundred yards apart, picking. up snakes, lizards, frogs, or fish, according to the locality. Just after this I had occasion to make a six days' journey to the south-east; the Storks were everywhere, among rocks on the hills, in olive-yards, sandy plains, on the dunghills of villages, on the top of Nebo. They remained apparently until they had cleared off the reptilian harvest, and departed for the north as suddenly as they came. A very few pairs here and there remain to breed, notably among the ruins of Gerash and Ammon, perhaps also at Cesarea. They showed great confidence in man, and are never molested by the natives."

Both sexes are alike in plumage; but the female is somewhat smaller than the male; and the young, when fledged, do not differ from their parents except in the darker colouring of their bills and legs. To show the difficulty of obtaining a young chick of this species, I may mention that for ten years I solicited my Continental correspondents to obtain me one withont success, until at length my old and valued friend Professor Kaup, of Darmstadt, knowing that I required it purely for a scientific purpose, not only sent me a specimen, but also a drawing from life, by which means I have been able to portray correctly the colouring of the soft parts-for which act of attention I here record my thanks.

The upper part of an adult, and the young, are represented of the size of life. 


\section{$2 \mathrm{BHL}$ Biodiversity Heritage Library}

Gould, John. 1873. "Stork, Ciconia alba [PI. 30]." The birds of Great Britain 4, -. https://doi.org/10.5962/p.323989.

View This Item Online: https://www.biodiversitylibrary.org/item/221609

DOI: https://doi.org/10.5962/p.323989

Permalink: https://www.biodiversitylibrary.org/partpdf/323989

\section{Holding Institution}

Smithsonian Libraries

\section{Sponsored by}

Biodiversity Heritage Library

\section{Copyright \& Reuse}

Copyright Status: Public domain. The BHL considers that this work is no longer under copyright protection.

This document was created from content at the Biodiversity Heritage Library, the world's largest open access digital library for biodiversity literature and archives. Visit BHL at https://www.biodiversitylibrary.org. 